\title{
線形座屈荷重最大化と部材長一様化を目的とした 単層ラチスシェルの形状最適化 \\ SHAPE OPTIMIZATION OF SINGLE-LAYER LATTICED SHELLS FOR MAXIMUM LINEAR BUCKLING LOAPSS AND UNIFORM MEMBER LENGTHS
}

\author{
小河利行*, 大崎 “純**, 立石理恵*** \\ Toshiyuki OGAWA, Makoto OHSAKI and Rie TATEISHI
}

\begin{abstract}
Optimal shapes are found for latticed shells defined by Bézier surfaces. The linear buckling load factor is first maximized under constraints on slenderness ratios of members. Optimization problems for minimizing the difference between the maximum and minimum lengths among the specified members are successively'solved to obtain an optimal shape in view of construction efficiency. The geometrically nonlinear properties of optimal solutions are investigated to find that the applied loads are transmitted to the supports through axial forces rather than bending moments. It is shown that the nonlinear buckling loads are successfully increased by optimizing the shape with respect to linear buckling loads, and that no significant increase is observed in the imperfection sensitivity as the result of optimization.
\end{abstract}

Keywords : Shape optimization, Linear buckling load factor, Rigidly jointed single-layer latticed shell, Bézier surface, Geometrically nonlinear elastic analysis, Geometrical initial imperfection 形状最適化, 線形座屈荷重係数, 剛接合単層ラチスシェル, ベジエ曲面, 弾性非線形解析, 形状初 期不整

\section{1 : 序論}

近年, 計算機や構造工学の技術の進歩により, 古典的な 2次曲面 などの解析曲面では表すことのできない，任意形状曲面を持った大 空間構造物の設計の可能性が広がっている。解析的表現ではなくパ ラメトリックな表現によって曲面を生成する方法は, CAGD (Computer Aided Geometric Design) ${ }^{3) ~ 6)}$ と呼ばれ，航空機や自動車，船 舶の設計に利用されてきた。パラメトリック曲面の中で, 最も単純 な曲面がベジエ曲面である。建築の分野でも，ベジエ曲面を用いて シェル曲面の形状や剛性分布を最適化した例がみられる73,8)。さら に, 立体トラスなどの部材で構成される大空間構造物の形状を最適 化した例もみられる9)。

大空間構造物の中でも，単層ラチスシェル構造は，スレンダーな 外観と美しさを持ち合わせており，その軽快さや透明感からデザイ ン面でも注目されている。しかし，面内剛性に比べ面外剛性がはる かに小さいため，座屈などの不安定現象に対して十分な安全性を有 するように設計されなければならない10),11。さらに,曲率を有する構 造物は, 分布する荷重を面内を流れる力により支点に伝達するため, 力の流れを規定する曲面形状の選択は重要な問題である。力学的特 性を考虑した形状最適化問題については, 剛性に着目した小河ら ${ }^{12)}$,

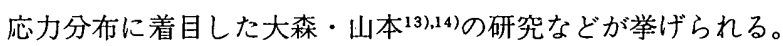

座屈荷重を考慮した最適化手法が提案されたのは，1960年代まで 遡る。Prager and Taylor ${ }^{15}$ 'は, 座屈前変形を無視できる場合を想 定した上で, 線形座屈荷重係数制約条件下での最適化問題を定式化 し, 単純な柱状構造物に対して最適性条件を導いている。Olhoff and Rasmussen ${ }^{16)}$ は, 両端を固定された柱の座屈に対して最適剛性分布
を求めた場合, 座屈荷重係数が重複することを明らかにした。 Ramm et al. ${ }^{7}$ は, 連続体シェルを対象として線形座屈荷重係数最大 化を試みている。立体トラスなどの空間構造物に対しては，座屈前 変形を考虑した非線形座㐿に基づいて最適化が行われてい る17) 21)。しかし, これらの研究は部材の剛性を最適化するものであ $\eta$, 形状は考慮されていない。一般にラチスシェルは, 形状初期不 整敏感度が大きく22) 24)，また, 座屈に至るまでに大きく変形するた め, 座屈酎力を評価する際には, 座屈前変形に伴う幾何学的非線形

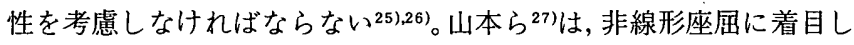
たスペースフレームの形状最適化を行っているが，形状変更の自由 度が一方向であるため，スムーズな部材配置が得られていない。一 方, Ohsaki ${ }^{28)}$ は, 立体トラスの部材断面樻最適化を行い, 線形座屈 と非線形座屈の定式化をそれぞれ用いた場合, 断面積の大きさは異 なるが，その分布の傾向は類似することを例示している。そこで本 論では, 最も簡単な座屈荷重の算定法である線形座屈を考慮した形 状最適化を行い, 併せて得られた最適形状に対し, 幾何学的非線形 性による影響を弾性非線形解析を用いて検証する。

大空間構造物においては，デザイン性と並んで施工性も重要な問 題となる。ところが, 力学的な観点から形状最適化を行うと部材長 の異なる部材が多数存在し, 施工性が悪くなることが予想される。 石川ら ${ }^{299}$ は，ラチスシェルの部材長の偏差量を最小化するような節 点位置を求める手法を提案しているものの, 偏差量が小さくなって も部材種類が限定されることにはならない。また, 大澤ら 幾何学的手法によるグリッド分割法を示し, Tarnai ${ }^{31}$ は, 部材長の 種類を最小化するようなジオデシックドームについて理論的な考察
本諭文の一部は，参考文献1)，2）で発表した。

* 東京工業大学大学院理工学研究科建築学専攻 教授・工博

** 京都大学大学院工学研究科建築学尃攻 助教授 · 博士 (工学)

*** 侏) CRCソリューションズ 修士(工学) (元東京工業大学 大学院生)
Prof., Dept. of Arch. and Building Engng., Tokyo Institute of Technology, Dr. Eng. Assoc. Prof., Dept. of Arch. and Architectural Systems, Kyoto Univ., Dr. Eng.

CRC Solutions Corporation, M. Eng.

(Ex-Graduate Student, Tokyo Institute of Technology) 
を行った。しかし，分割の種類に依存せず，部材長の種類を最小化 するような一般的な最適化手法は存在しない。

以上より本論では，ベジエ曲面によって記述された単層ラチス自 由曲面シェルを対象として, 線形座屈荷重を最大化する形状最適化 を行い, 構造物の力学的能力を十分に発揮できる形態を創生するこ とを目的とする。具体的には，まず部材長さに関する制約条件の下， 線形座屈荷重係数を最大化し，その上で部材長さを揃える工夫を試 みる。また，最適解の形状や力学特性からその性質を考察する。最 後に，最適形状に对し非線形座屈荷重を求め，さらに形状初期不整 に対する敏感性を検討し，最適解の有効性を検証する。

\section{2. 単層ラチスシェル曲面の記述法}

曲面の記述方法として, $n \times m$ 次テンソル積ベジエ曲面(以下べジ エ曲面）を用いる。曲面形状を定義する実空間座標内の制御点べク トルを $\boldsymbol{R}_{a, \beta}^{\prime}$ とし， $u, v(0 \leq u, v \leq 1)$ をパラメータとすると, ベシ 工曲面 $\boldsymbol{X}(u, v)$ は，バーンス夕イン基底関数 $B_{\alpha}^{n}$ ，および $B_{\beta}^{m}(\alpha=$ $1 \ldots n, \beta=1 \ldots m)$ を用いて式(2.1)で表され，パラメー夕值 $(u, v)$ により定められる曲面である。

$$
\boldsymbol{X}(u, v)=\sum_{\alpha=0}^{n} \sum_{\beta=0}^{m} \boldsymbol{R}_{\alpha, \beta}^{\prime} B_{\alpha}^{n}(u) B_{\beta}^{m}(v)
$$

ここで $\boldsymbol{R}_{\alpha, \beta}^{\prime}$ は，アフィン変換により式(2.2)のように定義される ものとする。アフィン変換を用いることにより，幾何学的な性質を 保ちながら，正規化された空間から実空間への変換を行うことがで き，様々な形状を統一的に評価することが可能となる。

$$
\boldsymbol{R}_{\alpha, \beta}^{\prime}=\boldsymbol{T} \boldsymbol{R}_{\alpha, \beta}
$$

なお，最適化問題において，制御点べクトルを設計変数とする場 合この $\boldsymbol{R}_{\alpha, \beta}$ を用いることとする。またアフィン変換行列 $\boldsymbol{T}$ は, 最適 化過程において固定する。

図 1 に制御ネットおよびベジエ曲面を示す。

が制御点，太線が 制御ネットを表し，細線がベジエ曲面を表す。本論では，式(2.1)に おける次数 $n, m$ を，滑らかな曲面を表現でき，かつ形状変更の自由 度を保つよう $n=m=5$ とする。また計算負荷低減のため, 曲面は $u=0.5, v=0.5$ において対称なものとし, 図 1 に示すように網掛け 部分内の $9 つ の$ 制御点の座標ベクトル $\boldsymbol{R}_{\alpha, \beta}$ を用いて解析を行うこ ととする。

\section{3. 座屈荷重最大化問題の定式化}

基準荷重ベクトル $P_{0}$ を定め, 荷重係数 $\mu$ をパラメータとして, 比 例載荷荷重 $\mu \boldsymbol{P}_{0}$ を作用させる。この時，部材長さに関する制約を与 之，先に述べた $\boldsymbol{R}_{\alpha, \beta}$ および節点パラメータ $u, v$ に関する指標を設 計変数として線形座屈荷重の最大化を行う。線形剛性行列および幾 何剛性行列をそれぞれ $\boldsymbol{K}_{L}, \boldsymbol{K}_{G}$ とおくと, $r$ 次座屈モード $\Phi_{r}$ とこれ
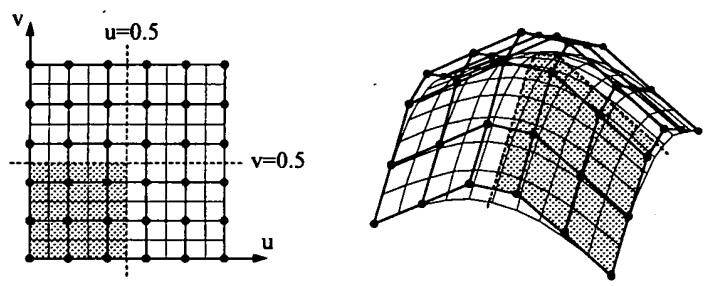

図 1 制穊ネットおよびベジエ曲面
に対応する線形座屈荷重係数 $\mu_{r}$ は, 次の固有值問題 (3.1)の解である。

$$
\left(\boldsymbol{K}_{L}+\mu_{r} \boldsymbol{K}_{G}\right) \Phi_{r}=\mathbf{0}
$$

線形座屈荷重は, $\mu^{c} を \mu_{r}$ の正の最小值 ( 1 次線形座屈荷重係数) とすると $\mu^{c} \boldsymbol{P}_{0}$ と定義されることから，目的関数を $\mu^{c}$ と設定する。

\section{4. 形状最適化問題}

べジエ曲面によって決定された $\boldsymbol{X}(u, v)$ 上に節点を持ち, 正方形 平面を有する剛接合単層ラチスシェルを初期形状とし, 最適形状を 求める。ここで, 式(2.2)で示したアフィン変換行列 $T$ は, 式(4.1) で与えることとする。なお,式(4.1)において長さの単位は $\mathrm{m}$ である。

$$
\boldsymbol{T}=\left[\begin{array}{ccc}
50 & 0 & 0 \\
0 & 50 & 0 \\
0 & 0 & 50
\end{array}\right]
$$

初期モデルおよび形状諸元を図 2 に示す。初期モデルは, 式 (4.2) で定義される。境界において $x$ 軸， $y$ 軸に対して曲率を持つ $\mathrm{A}$ -model と, 式 (4.3)で定義される, 正方形の境界を持つ B-model と する。

A-model

$$
\begin{array}{lll}
\boldsymbol{R}_{0,0}=(0,0,0), & \boldsymbol{R}_{0,1}=(0,0.2,0.08), & \boldsymbol{R}_{0,2}=(0,0.4,0.12) \\
\boldsymbol{R}_{1,0}=(0.2,0,0.08), & \boldsymbol{R}_{1,1}=(0.2,0.2,0.12), & \boldsymbol{R}_{1,2}=(0.2,0.4,0.15) \\
\boldsymbol{R}_{2,0}=(0.4,0,0.12), & \boldsymbol{R}_{2,1}=(0.4,0.2,0.15), & \boldsymbol{R}_{2,2}=(0.4,0.4,0.2)
\end{array}
$$

B-model

$$
\begin{array}{lll}
\boldsymbol{R}_{0,0}=(0,0,0), & \boldsymbol{R}_{0,1}=(0,0.2,0), & \boldsymbol{R}_{0,2}=(0,0.4,0) \\
\boldsymbol{R}_{1,0}=(0.2,0,0), & \boldsymbol{R}_{1,1}=(0.2,0.2,0.1), & \boldsymbol{R}_{1,2}=(0.2,0.4,0.15) \\
\boldsymbol{R}_{2,0}=(0.4,0,0), & \boldsymbol{R}_{2,1}=(0.4,0.2,0.15), & \boldsymbol{R}_{2,2}=(0.4,0.4,0.2)
\end{array}
$$

また，格子タイプは 2 方向と 4 方向の 2 種類とし，4つの初期形 状を考える。以下これらのモデルを，A2-model，A4-model， B2-model, B4-model と表現する。図 2 のモデルは, (1) A2-model, (2) B4-model である。部材諸元を表 1 に示す。構成部材は全て円形 鋼管を用い， 4 方向格子の斜材は, 弦材の $1 / 10$ 程度の断面積として
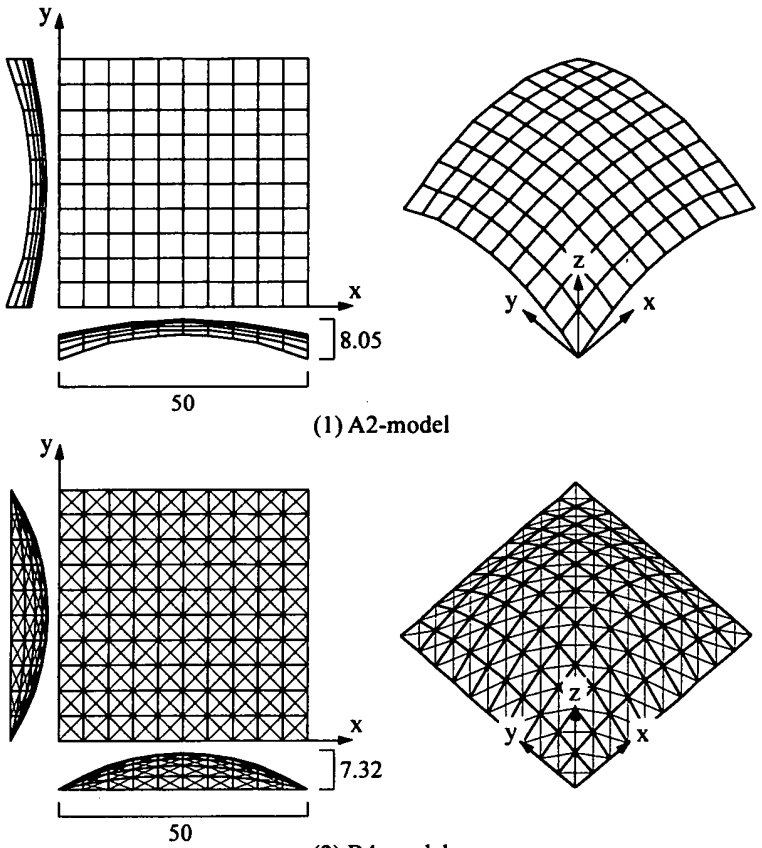

A2-model

(2) B4-model

図 2 初期モデルおよU゙形状諸元 （単位：m） 
いる。図 3 に境界条件および荷重載荷条件を示す。線形固有值解析 において, 境界条件は全周ピン支持とする。また荷重は等分布荷重 とし，図 3 に示すように，それぞれのモデルの頂部節点において， 部材が降伏軸力 $N_{y}$ に達する際の荷重を降伏荷重 $p_{y}$ とし, $p_{y}$ の $5 \%$ の荷重を基準荷重 $p_{0}$ と設定する。ただし 4 方向モデルの場合, 弦材が降伏した際の斜材の軸力も加えることとする。表 2 に初期モデ ルの線形座屈荷重係数 $\mu^{c}{ }_{\mathrm{Inn}}$, 降伏荷重 $p_{y}$, および基準荷重 $p_{0}$ を示す。

解析パラメータとして設計変数の個数を考之る。図 4 (1)および(2) に, 節点位置を決めるパラメータ $u, v$ および正規化された空間内の 制御点ベクトル $\boldsymbol{R}_{\alpha, \beta}$ の設定法をそれぞれ示す。節点位置を決めるパ ラメータ $u, v て ゙ は ， 4$ 分の1に対して図4(1)のように $u_{i j}, v_{i j}(i=$ $1 \ldots 6, j=1 . .66)$ と表し， $u_{i j}, v_{i j}$ を等分割に配置するタイプと， $u_{i j}$ $(i=2 \ldots 5, j=1 . . .6)$ を独立した変数とするタイプの 2 タイプ考える。 ただし， $u$ 方向， $v$ 方向は対称とし， $u_{i j}=v_{j, i}$ という条件を与える。 以下 $u_{i j}(i=2 \ldots 5, j=1 \ldots 6)$ を変数べクトル $\boldsymbol{u}^{*}$ と表す。また節点位 置 $\boldsymbol{R}_{\alpha, \beta}$ では，節点 5 〜 9 のれぞれ 3 軸 $(x ; y, z)$ 方向に対して形 状変更の自由度を与えたタイプ(R12) と, それに加え, 節点 $2,3 の$ 2 軸 $(y, z)$ 方向, 節点 4,7 の 2 軸 $(x, z)$ 方向に対して形状変更の 自由度を与えたタイプ(R20)の 2 タイプ考之る。両者の差異は, 境界 辺上における自由度の有無である。

\section{1 部材細長比を制約条件とした座屆荷重最大化（P1）}

制約条件として各部材細長比 $\lambda_{k}$ の值に上限值 $\lambda_{\text {max }}$.下限值 $\lambda_{\min }$ を, 節点位置 $\boldsymbol{R}_{\alpha, \beta}$ の值に上限值 $R_{\max }$. 下限值 $R_{\min }$ を与之, 線形座 屈荷重を最大化することを考える。この形状最適化問題を P1とする と，P1は次のように書くことができる。

表 1 ·部材諸元

\begin{tabular}{|c|c|c|c|c|}
\hline \multirow{2}{*}{\multicolumn{2}{|c|}{ Chord(C) or Diagonal(D) member }} & \multirow{2}{*}{\begin{tabular}{|c|} 
A2-model, B2-model \\
$\mathrm{C}$ \\
\end{tabular}} & \multicolumn{2}{|c|}{ A4-model, B4-model } \\
\hline & & & C & D \\
\hline Member slenderness ratio & $\lambda$ & $45.39 \sim 48.22$ & $45.37 \sim 51.78$ & 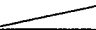 \\
\hline Diameter & $\phi(\mathrm{cm})$ & 31.85 & 31.85 & 7.63 \\
\hline Thickness & $t(\mathrm{~cm})$ & 0.69 & 0.69 & 0.28 \\
\hline Sectional area & $A\left(\mathrm{~cm}^{2}\right)$ & 67.55 & 67.55 & 6.465 \\
\hline Moment of inèrtia & $I\left(\mathrm{~cm}^{4}\right)$ & 8202 & 8202 & 43.7 \\
\hline Radius of gyration & $i(\mathrm{~cm})$ & 11.02 & 11.02 & 2.60 \\
\hline Young's modulus & $\left(\mathrm{kN} / \mathrm{mm}^{2}\right)$ & . & 205.94 & \\
\hline Yeild stress & $\alpha_{y}\left(\mathrm{kN} / \mathrm{cm}^{2}\right)$ & & 23.53 & \\
\hline
\end{tabular}
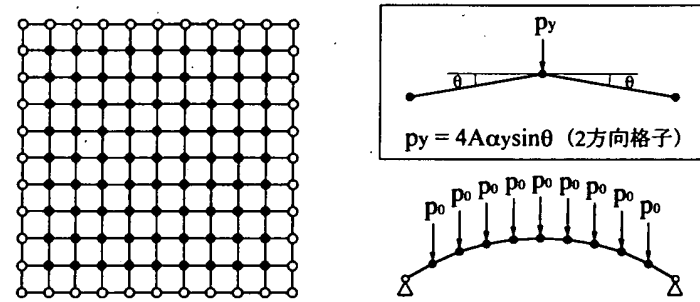

荷重載荷点 $\bigcirc$ ピン支持

図 3 境界条件およU゙荷重載荷条件

表 2 初期モデルにおける線形座屈荷重係数、 $\mu^{c}{ }^{\mathrm{Int}}$ および降伏荷重 $p_{y}$, 基準荷重 $p_{0}$

\begin{tabular}{|c|c|c|c|c|}
\hline & A2-model & A4-model & B2-model & B4-model \\
\hline Linear buckling load factor $\mu{ }^{{ }^{c}}$ im & 18.83 & 30.46 & 19.57 & 38.28 \\
\hline Yeild load & 192.26 & 210.95 & 348.23 & 352.04 \\
\hline Unit loading & 9.61 & 10.55 & 17.41 & 17.60 \\
\hline
\end{tabular}

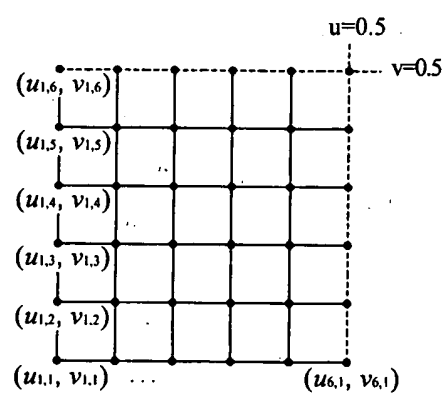

(1) 節点位直を決めるパラメータ $u, v$

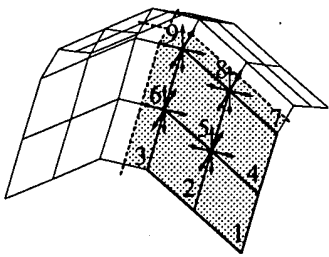

(a) R12：節点 12 自由度

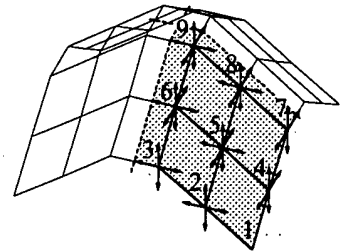

(b) R20：節点 20 自由度
(2) 節点位置 $\boldsymbol{R}_{\alpha, \beta}$

図 4 設計変数の設定方法

$\begin{array}{rlr}\text { P1 } & \text { Maximize }: & \mu^{c} \\ \text { Subject to }: & \lambda_{\min } \leqq \lambda_{k} \leqq \lambda_{\max } \quad\left(k=1, \ldots, N_{c}\right) \\ & \boldsymbol{R}_{\alpha, \beta}{ }^{\min } \leqq \boldsymbol{R}_{\alpha, \beta} \leqq \boldsymbol{R}_{\alpha, \beta}{ }^{\max } \\ \text { Variables }: & \boldsymbol{R}_{\alpha, \beta}\end{array}$

ここで， $N_{c}$ は制約を考慮する部材の数であり，本研究では弦材の みを考之 $N_{c}=220$ とする。なお，設計変数は $\boldsymbol{R}_{\alpha, \beta}$ のみとする。

\section{2. 座屈荷重最大化と部材のグループ化（P2）}

線形座屈荷重だけでなく, 部材長さを揃え，部材種類を少なくす ることに重点を置いた形状最適化問題について考える。

まず，P1と同様に $\mu^{c}$ を最大化し，各部材長さ $l_{k}$ に対して制約条 件式 (4.7)を与えた形状最適化問題を P2-1とする。

\begin{tabular}{|rlr|}
\hline P2-1 Maximize $: \mu^{c}$ & $(4.6)$ \\
Subject to $:$ & $\left|\mathrm{L}_{a v e}{ }^{\mathrm{P} 2-1}-l_{k}\right| \leqq e \mathrm{~L}_{a v e}{ }^{\mathrm{P} 2-1}$ & $\left(k=1, \ldots, N_{c}\right)$ \\
& & $(4.7)$ \\
& $\mathrm{L}_{a v e^{\mathrm{P} 2-1}}=\left(\mathrm{L}_{\max }{ }^{\mathrm{P} 2-1}+\mathrm{L}_{\min }{ }^{\mathrm{P} 2-1}\right) / 2.0$ & $(4.8)$ \\
& $\boldsymbol{R}_{\alpha, \beta}{ }^{\mathrm{min}} \leqq \boldsymbol{R}_{\alpha, \beta} \leqq \boldsymbol{R}_{\alpha, \beta}{ }^{\max }$ & $(4.9)$ \\
Variables & $: \boldsymbol{R}_{a, \beta}$ & $(4.10)$ \\
\hline
\end{tabular}

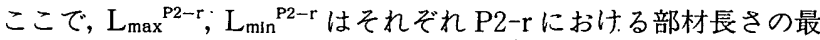
大值, 最小值であり, $\mathrm{L}_{\text {ave }}{ }^{\mathrm{P} 2-1}$ は $\mathrm{L}_{\max }{ }^{\mathrm{P} 2-1}$ と $\mathrm{L}_{\min }{ }^{\mathrm{P} 2-1}$ の平均值である。 また許容誤差として, $e \mathrm{~L}_{a v e} e^{2-1}$ をちえ, $e$ は微小な值とする。P1同様, 設計変数は $\boldsymbol{R}_{\alpha, \beta}$ のみとする。

次に, $\mathrm{P} 2-1$ の最適形状を初期形状として, $L_{\max }{ }^{\mathrm{P} 2-2}$ と $L_{\min }{ }^{\mathrm{P} 2-2}$ の差 を最小化する形状最適化問題 P2-2を考える。ただし，P2-2におい て, $L_{\max }{ }^{\mathrm{P} 2-2}$ と $L_{\min }{ }^{\mathrm{P} 2-2}$ は変数とみなすことができ, P2-1より変数が 增えている。

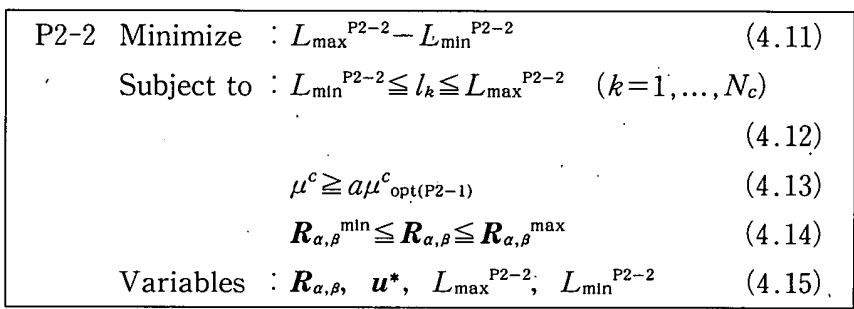


制約条件は部材長さに関する式(4.12)と，P2-1で得られた座屈荷 重係数 $\mu_{\mathrm{opt}(\mathrm{P} 2-1)}^{c}$ が,一定の值以上低下しないよう設定した式(4.13) の 2 つとし， $a$ は 1 より少し小さい值を与える。ここで，制約条件 (4.12)においてアクティブとなる部材の集合を S1と定義すること とする。なお，設計変数は $\boldsymbol{R}_{\alpha, \beta}, \boldsymbol{u}^{*}$ を考之る。

最後に，P2-2の最適形状を初期形状として，P2-2において制約条 件 (4.12)がアクティブとなった部材（集合 S1）には制約条件 (4.17) を，その他の部材には制約条件 (4.18)を与え，グループ化された部 材に対し，それぞれ異なる制約条件とする形状最適化問題 P2-3を考 える。

\begin{tabular}{|c|c|c|c|}
\hline \multirow[t]{6}{*}{$\mathrm{P} 2-3$} & Minimize & $L_{\max }{ }^{\mathrm{p} 2-3}-L_{\operatorname{mln}}^{\mathrm{P} 2-3}$ & $(4.16)$ \\
\hline & Subject to & $\mathrm{L}_{\min }{ }^{\mathrm{P} 2-2} \leqq l_{k} \leqq \mathrm{~L}_{\max }{ }^{\mathrm{P} 2-2} \quad\left(l_{k} \in \mathrm{S} 1\right)$ & $(4.17)$ \\
\hline & & $L_{\min }{ }^{\mathrm{P} 2-3} \leqq l_{k} \leqq L_{\max }^{\mathrm{P} 2-3} \quad\left(l_{k} \oplus \mathrm{S} 1\right)$ & $(4.18)$ \\
\hline & & $\mu^{c} \geqq a \mu_{\mathrm{opt}(\mathrm{P} 2-1)}^{c}$ & $(4.19)$ \\
\hline & & $\boldsymbol{R}_{\alpha, \beta}{ }^{\min } \leqq \boldsymbol{R}_{\alpha, \beta} \leqq \boldsymbol{R}_{\alpha, \beta}^{\max }$ & $(4.20)$ \\
\hline & Variables & $\boldsymbol{R}_{\alpha, \beta}, \quad \boldsymbol{u}^{*}, \quad L_{\max }{ }^{\mathrm{P} 2-3}, \quad L_{\min }{ }^{\mathrm{P} 2-3}$ & $(4.21)$ \\
\hline
\end{tabular}

この P2-3以下，解の収束が終了するまで P2-4，P2-5...を繰り返 す。また各最適化問題において，P2-2と同様，制約条件がアクティ ブとなる部材の集合を S2, S3...と呼ぶ。

\section{5. 解析結果}

前章で提示した形状最適化問題 P1, P2-rに対し, 改訂許容方向法
を用いて解を求める。なお, 全ての問題において, 全節点で $\boldsymbol{R}_{\alpha, \beta}{ }^{\mathrm{m} \mid \mathrm{n}}=$ $(0.0,0.0,0.0), \boldsymbol{R}_{\alpha, \beta}{ }^{\max }=(1.0,1.0,1.0)$ と設定することとし, P1に おいて, $\lambda_{\min }=30, \lambda_{\max }=60, \mathrm{P} 2-1 に お い て, e=0.1,0.05, a=0.9$ として解析を行う。

\section{1 座屈荷重最大化 (P1) 最適形状および最適解}

図 5 にP1の最適形状および最適解を示す。図中の立面図におい て, 上が初期形状, 下が最適形状を表し, 最適形状における線形座 屈荷重係数を $\mu_{\mathrm{opt}}^{c}$, シェルのライズを $h$ とする。全てのモデルにお いて, 最適形状は, ライズの上昨した球に近い丸みを帯じた形状と なっている。これは, 扁平なラチスシェルで起こり得る不安定現象 を回避するためと考えられ, 最適形状のライズは, 初期モデルの 1.99 2.28倍まで上昇し, 座屈荷重係数 $\mu^{c}$ は3.08 8.08倍まで增 加している。(1) A2-model R12と(2) A2-model R20を比較すると, 境 界辺上節点の $z$ 軸方向に形状変更可能な(2) A2-model R20は, 境界 辺上節点が下がク，B-modelに近い形状となるのが特徽的である。 さらに境界辺周辺の部材が中心に集まり，(1) A2-model R12と比べ ると，より丸みを帯びた形状となり，格子形状が直交ではなくなっ ているのが分かる。A4-modelにおいても同様に, (4) A4-model R20 は境界辺上節点が下がり，また境界周辺の部材が中心に集まってい る。しかし, (3) A4-model R12, (4) A4-model R20ともにA2-model と比べると，ライズの低い形状となっている。一方，(6) B2-model R20と(8) B4-model R20では, A2-model, A4-model 同様, 境界周

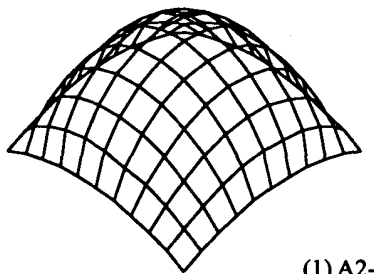

(1) A2-model R12

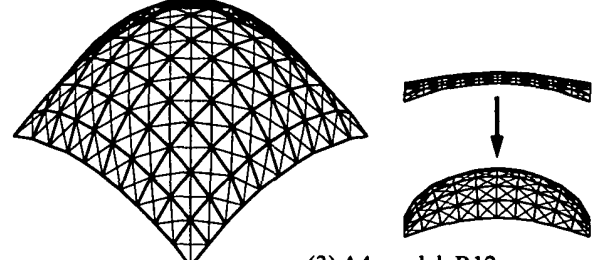

(3) A4-model R12
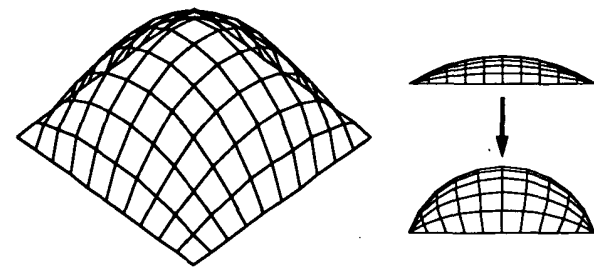

(5) B2-model R12
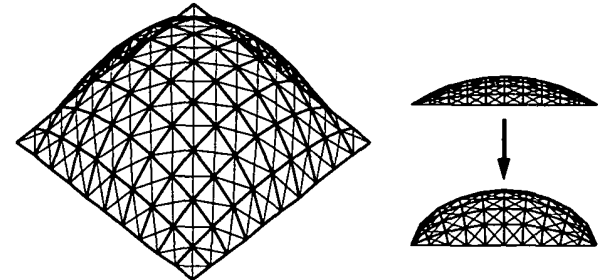

(7) B4-model R12
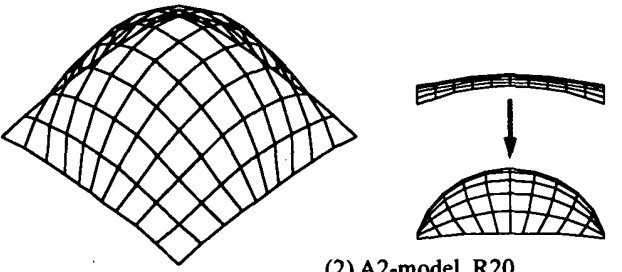

$\mu_{\mathrm{opt}}=113.75$ $\kappa_{\text {opt }} / \mu_{\text {int }}=6.04$ $h=19.75 \mathrm{~m}$

(2) A2-model R20
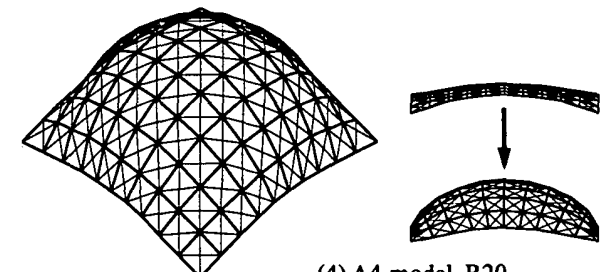

$\mu_{\text {opt }}=236.47$ $\mu_{\text {opt }} / \mu_{\text {int }}=7.76$ $\mu_{\text {opt }} / \mu_{\text {iat }}^{c}=8.08$ $h=18.61 \mathrm{~m}$

(4) A4-model R20
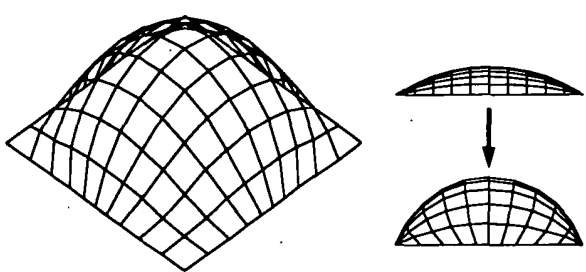

$\mu_{\text {opt }}=63.98$

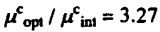
$\mu_{\text {opt }}^{c_{\text {opt }}} / \mu_{\text {idt }}^{c_{\text {id }}}=3.08$ $h=17.33 \mathrm{~m}$

(6) B2-model R20
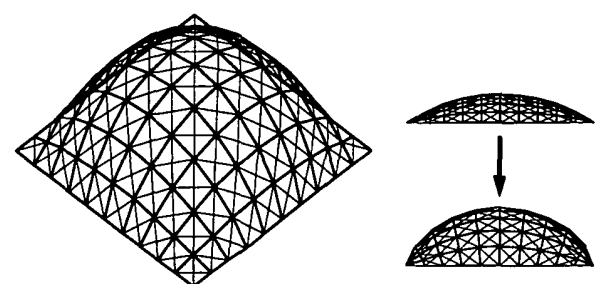

$\mu_{\text {opt }}^{\varepsilon}=154.49$ $\mu_{\text {opt }}^{c} / \mu_{\text {int }}^{c_{\text {int }}}=4.04$ $\mu_{\text {opt }} / \mu_{\text {int }}=3.80$ $h=14.60 \mathrm{~m}$

(8) B4-model R20

図 $5 \mathrm{P} 1$ ：部材細長比を制約条件とした座屈荷重最大化問題の最適形状および最適解 
辺の部材が中心に集まる特徵を持っているものの，境界辺上節点の $z$ 軸方向に変化は見られず, (5) B2-model R12や(7) B4-model R12 と 同じ境界形状となっている。また，B-modelにおいても，B2-model と比べ B4-model の方が，ライズの低い形状となっている。

5.2 座屈荷重最大化と部材のグループ化 (P2) 最適形状および最適解 図 6 に P2-rにおける A2-model R20の解析結果を示す。それぞれ P2-5，P2-6まで最適化問題を繰り返した結果となっており，P2-5, P2-6が終了した時点での最終形状を最適形状とする。(1-a)は $e=$ 0.05 とした場合の最適形状および各最適化問題における最適解であ ク, (1-b)は P2-2終了時, (1-c) はP2-5終了時における部材種類を示 す。ただし，対称性を考慮し，8分の 1 平面内の部材のみ記してい る。同様に，(2-a)，(2-b) および $(2-\mathrm{c})$ は $e=0.1$ とした場合の結果 である。(1) $e=0.05$ では $L_{\max }{ }^{\mathrm{P} 2-\mathrm{r}}-L_{\mathrm{m} 1 \mathrm{n}}{ }^{\mathrm{P} 2-\mathrm{r}}$ が50.7cm から $18.0 \mathrm{~cm}$ までおよそ64\%減少している。同一グループとみなすための許容誤 差を，例えば $0.6 \mathrm{~cm}$ とすると，(1-b)，(1-c)に示すように，P2-2の 段階では部材種類は16種類であり，まだ部材長さは疎らであるが, $\mathrm{P} 2-5$ 終了時では部材種類は 12 種類となり，部材長さはかなり揃って

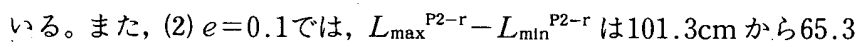
$\mathrm{cm}$ までおよそ36\%減少し, 部材種類は24種類から19種類にまで減 少している。両モデル共に, 繰り返しの過程において部材が徐々に グループ分けされていき, 部材種類が減少したことで部材長さの 揃った形状が得られた。一方で $\mu^{c} と h$ は P2-2から P2-5, P2-6の間 にほとんど変化せず，初期形状に比べると，(1) $e=0.05 て ゙ は \mu^{c}$ は 2.10倍, $h$ は1.25倍, (2) $e=0.1 て ゙ は \mu^{c}$ は3:17倍, $h$ は 1.48 倍である。 どちらもライズの上䒜は見られるが，P1の最適形状ほどではなく， 格子形状はほぼ直交を保っている。また, P2-2において, 式(4.7)で 表される制約条件の制約を緩めた(2)では,(1)と比べライズの上昇した 形状となっており, $L_{\max }{ }^{\mathrm{P} 2-\mathrm{r}}-L_{\mathrm{min}}{ }^{\mathrm{P} 2-\mathrm{r}}$ の減少率は小さくなっている。

\section{6. 最適解の力学的性質}

前章では，様々な制約条件の下，座屈荷重および部材長さに着目 して形状最適化を行った。本章では, 最適形状の力学的性質を明ら かにし，どのようなメカニズムにより最適形状が選択されたかとい うことについて検討する。
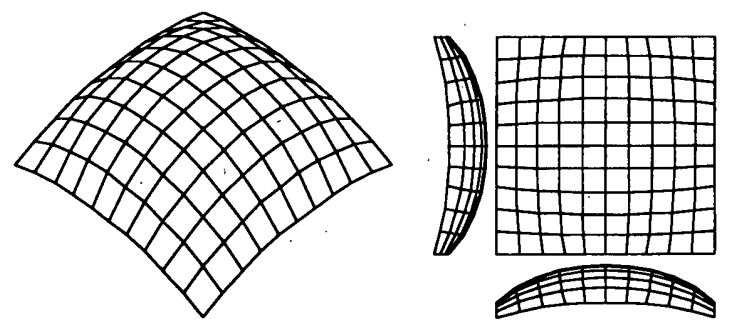

\begin{tabular}{|c|c|c|c|c|c|c|}
\hline & P2-1 & P2-2 & $\mathrm{P} 2-3$ & P2-4 & P2-5 & P2-6 \\
\hline$\mu^{\mathrm{c}}$ & 59.77 & 59.73 & 59.73 & 59.74 & 59.73 & 59.79 \\
\hline$L_{\text {max }}^{P_{2}-1}$ & 556.9 & 556.8 & 554.8 & 549.2 & 541.7 & 537.4 \\
\hline$L_{\min }^{p-1}$ & 455.6 & 455.7 & 457.3 & 461.5 & 467.3 & 472.1 \\
\hline$L_{\max }^{n-1}-L_{\min }^{p-1}(\mathrm{~cm})$ & 101.3 & 101.1 & 97.5 & 87.7 & 74.4 & 65.3 \\
\hline Number of groups & 24 & $\cdot 24$ & 24 & 23 & 23 & 19 \\
\hline (m) & 11.88 & 11.88 & 11.88 & 11.88 & 11.88 & 11.87 \\
\hline
\end{tabular}

(2-a) 最適形状（P2-6 終了時）および最適解

\begin{tabular}{|c|c|c|c|c|c|}
\hline 部材ダループ & 部材長さ $(\mathrm{cm})$ & 部材グルーフ & 部材長さ $(\mathrm{cm})$ & 部材タループ & 部材長さ $(\mathrm{cm})$ \\
\hline 1 & 456.1 & 11 & 529.1 & 17 & 536.3 \\
\hline 2 & 474.1 & \multirow{2}{*}{12} & 530.9 & \multirow{2}{*}{18} & 538.6 \\
\hline 3 & 493.0 & & 531.3 & & 538.7 \\
\hline 4 & 502.0 & 13 & 532.6 & \multirow{2}{*}{19} & 539.6 \\
\hline 5 & 507.1 & \multirow{2}{*}{14} & 533.9 & & 540.1 \\
\hline 6 & 515.7 & & 534.1 & 20 & 542.0 \\
\hline 7 & $\begin{array}{l}516.8 \\
\end{array}$ & \multirow{3}{*}{15} & 534.7 & 21 & 549.9 \\
\hline 8 & 519.1 & & 535.1 & 22 & 554.6 \\
\hline 9 & 525.1 & & 535.4 & 23 & 555.3 \\
\hline 10 & 528.5 & 16 & 536.1 & 24 & 556.4 \\
\hline
\end{tabular}

(2-b) 部材種類（P2-2 終了時）

\begin{tabular}{|c|c|c|c|c|c|}
\hline 部材タルルーフ & 部材長さ $(\mathrm{cm})$ & 部材ダルーフ & 部材良さ (cm) & T部材ダル:ープ & 部材長さ (cm) \\
\hline$\overline{1}$ & 458.0 & 9 & 529.4 & 14 & 536.8 \\
\hline 2 & 473.1 & \multirow{2}{*}{10} & 531.1 & \multirow{4}{*}{15} & 537.5 \\
\hline 3 & 493.5 & & 531.7 & & 537.5 \\
\hline 4 & 502.0 & 11 & 532.8 & & 537.5 \\
\hline 5 & 509.8 & 12 & 534.6 & & 537.5 \\
\hline \multirow{2}{*}{6} & 516.2 & \multirow{3}{*}{13} & 535.3 & 16 & .540 .9 \\
\hline & 516.7 & & 535.6 & 17 & 548.7 \\
\hline 7 & 519.4 & & 535.8 & \multirow{2}{*}{18} & 553.1 \\
\hline 8 & 525.1 & \multirow{2}{*}{.14} & 536.3 & & 553.6 \\
\hline 9 & 529.0 & & 536.5 & 19 & 556.5 \\
\hline
\end{tabular}

(2-c) 部材種類 (P2-6 終了時)

(2) A2-model R20 $\mathrm{e}=0.1$
(1) A2-model . R20 $\mathrm{e}=0.05$

\begin{tabular}{|c|c|c|}
\hline 516.8 & \multirow{6}{*}{9} & 5192 \\
\hline 516.8 & & 519.2 \\
\hline 518.3 & & 519.3 \\
\hline 518.4 & & 519.5 \\
\hline 518.5 & & 519.6 \\
\hline 518.7 & & 519.6 \\
\hline 519.0 & \multirow{2}{*}{10} & 520.3 \\
\hline 519.0 & & 520.3 \\
\hline 519.0 & 11 & 521.6 \\
\hline 519.1 & 12 & 527.8 \\
\hline
\end{tabular}

(1-c) 部材種類 (P2-5 終了時)

图 $6 \mathrm{P} 2-\mathrm{r}$ ：座屈荷重最大化と部材長のグループ化を考慮した形状最適化結果 
図 7 に各節点に基準荷重べクトル $\boldsymbol{P}_{0}$ を載荷した場合の, A2-model, A4-model の初期形状および最適形状における軸力図, 曲げモーメント図を示す。上が軸力図，下が曲げモーメント図であ る。軸力図において網掛けが圧縮材，白抜きが引張材を表し，曲げ モーメント図では，煩雑さを避けるため，対称性を考慮して一方向 のみを記述する。

初期形状では, A2-model, A4-model 共に, 端部に大きく曲げモ一 メントが発生しているが，最適形状では，それを抑えることができ ており，さらに P2では，全体的に曲げモーメントが小さくなってい る。これは，ライズが上昇し球に近い形状となることで 2 次曲げ応 力を抑之，軸力抵抗型の構造となったためと考えられる。一方，軸 力は初期形状に比へ，最適形状の方が全体的に小さくなっており， 特にP1でその傾向は大きい。また P 1 では, 境界から 1 つ内側の第 1 リングがテンション材となっているのが特徵的である。これは，格 子形状が直交でなくなることにより，スラストに対し第 1 リングが テンションリングの役割を担う構造となったためと考えられる。ここ には示していないが,他のモデルの場合もそれぞれ同様の傾向を持つ。

\section{7. 最適解の検証}

前章までに，線形座屈荷重を最大化する最適化を行い，得られた 最適形状の力学的性質を述べてきた。しかし, 扁平な単層ラチスシェ ルの場合, 座屈前の幾何学的非線形性が座屈耐力・座屈後の性状に 大きく影響を与えることが知られている。また，本論において对象 とした 2 方向格子シェルはアーチ的な要素が強く, 一般的なシェル と比へ初期不整敏感度が小さくなることが考えられるものの，6章 より最適形状は軸力抵抗型の構造となることが示されているため, 形状初期不整が座屈耐力低下の因子となる可能性がある。そこで本
章では，最適形状と初期形状に対し幾何学的非線形を考慮した弾性 非線形解析を行う。さらに形状初期不整が非線形座屈荷重に与之る 影響について検討し，最適解の検証を行う。

解析にあたってモデルは全体モデルとし，最適形状は扁平である ために，より不安定な挙動が予想される P2で得られた形状を用い, また形状変更における自由度が高いR20のモデルについて考察す る。なお，非線形座屈点は，釣り合い経路上で各変形状態における 推定線形座屈荷重を求め, この推定線形座屈荷重と荷重が一致する 点とし，その時の荷重を非線形座屈荷重 $P_{c r}^{e l}$ と定義する。

\section{1 幾何学的非線形を考慮した弾性非線形解析}

弾性非線形解析にお打る荷重一変位関係を図 8.に示す。図中の は非線形座屈点を表し，実線は最適形状，点線は初期形状の解析結 果である。(1) A-model の最適形状では, 初期形状と比べ, 斜材の有 無に関わらず, 非線形座屈荷重は大幅に増加し, 初期剛性も大きく なっている。一方，(2)-B-model の最適形状では，初期形状と比へ， A-model と同様に非線形座屈荷重は増加しているが, 初期剛性はほ とんど変わっていない。なお，どちらのモデルも変形は最適形状の 方が大きい。表 3 に初期形状と最適形状 $(\mathrm{P} 2-\mathrm{r})$ の線形座屈荷重 $P_{c r}^{l i n}$ および非線形座屈荷重 $P_{c r}^{e l}$ を示す。また $\mu_{\mathrm{int}}^{c}$ および $\mu_{\mathrm{opt}}^{c}$ も併せて 記す。初期形状と比べた最適形状の座屈荷重增加率を線形固有値解 析とのものと比較すると, 線形座屈荷重では, A2-model は2.12倍, A4-model は3.80倍, B2-model は1.26倍, B4-model は1.55倍と なっている一方で, 非線形座屈荷重では, A2-model は2.34倍, A4-model は4.24倍, B2-model は1.47倍, B4-model は1.79倍とい ずれも増加率は増大している。

\section{2 形状初期不整を考慮した弾性非線形解析}

前節では, 得られた最適形状が, 幾何学的非線形性を考慮した際

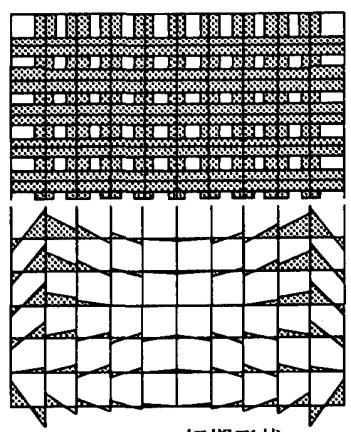

A2-model 初期形状

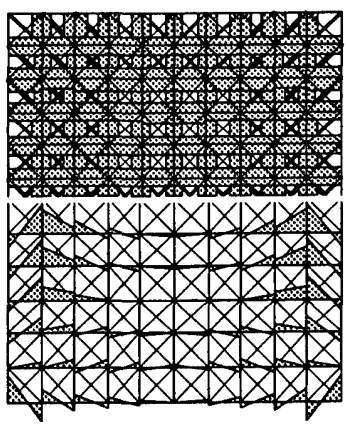

A4-model 初期形状

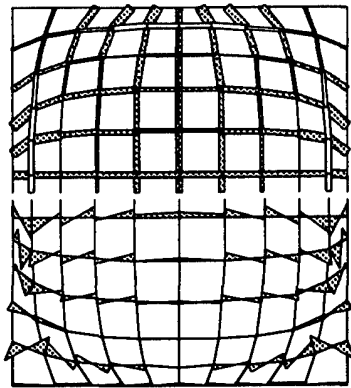

P1 : A2-model $\mathrm{R}=20$

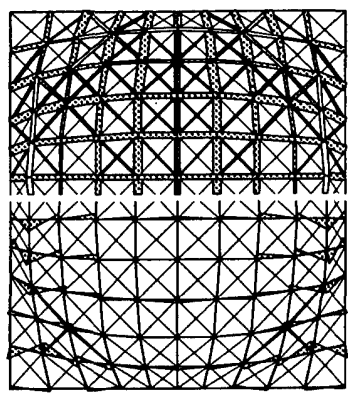

P1 : A4-model $\mathrm{R}=20$

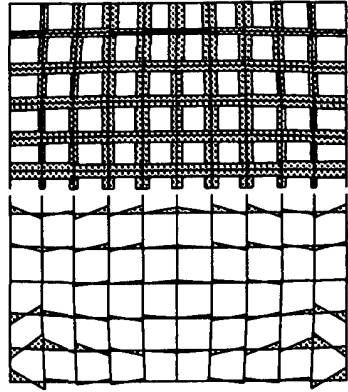

P2 : A2-model $R=20$

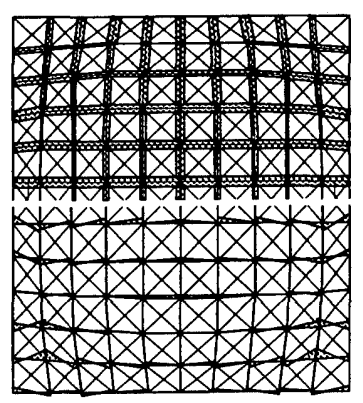

P2 : A4-model $\mathrm{R}=20$ $=200 \mathrm{kN} \square=200 \mathrm{kN} \quad=1000 \mathrm{kN} \cdot \mathrm{cm}$ 


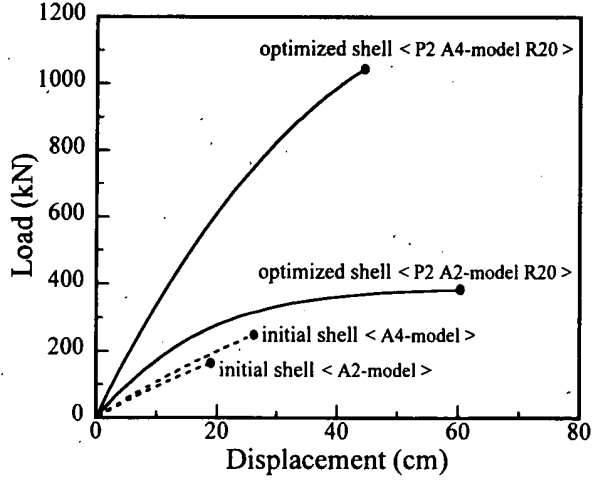

(1) A-model

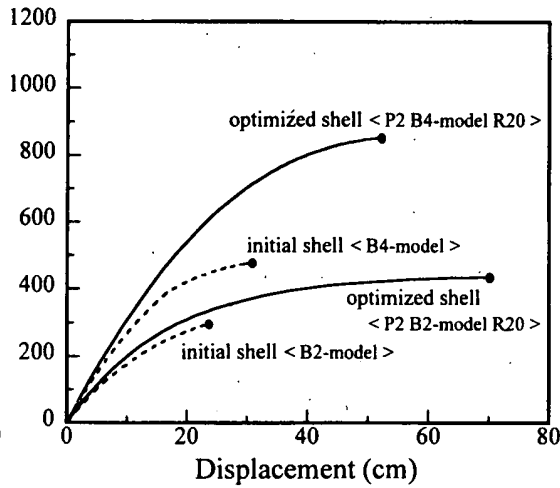

(2) B-model

図 8 弾性非線形解析 荷重一変位関係

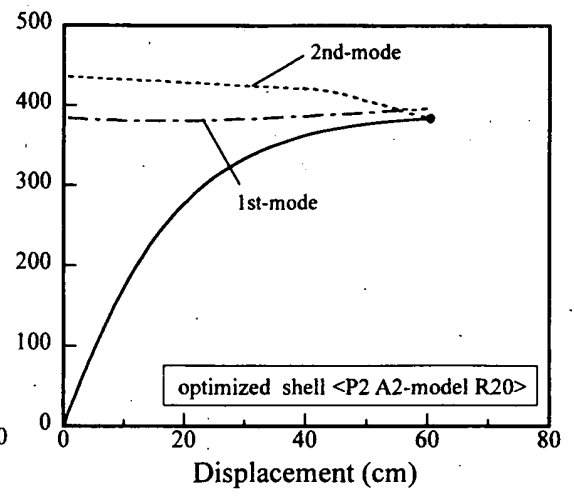

図 9 ·荷重一変位関係および各変形状態での 線形座屈荷重の推移
表 3 線形座屈荷重 $P_{c r}^{l i n}$ およU゙非線形座屈荷重 $P_{c r}^{e l}$

\begin{tabular}{|c|c|c|c|c|}
\hline & \multicolumn{4}{|c|}{ initial shell } \\
\hline & A2-model & A4-model & B2-model & B4-model \\
\hline$\mu \mu^{c}$ int & 18.83 & 30.46 & 19.57 & 38.28 \\
\hline$P_{\alpha} \operatorname{lin}^{\operatorname{lin}}$ & 181.85 & 325.13 & 343.53 & 672.77 \\
\hline$(\mathrm{kN})$ & 163.48 & 245.85 & 291.94 & 477.09 \\
\hline & \multicolumn{4}{|c|}{ optimized shell } \\
\hline & A2-model & A4-model & B2-model & B4-model \\
\hline$\mu_{\mathrm{opp}}^{\mathrm{c}}$ & 39.96 & 115.69 & 24.73 & 59.47 \\
\hline $\mathbf{P}_{s}^{\operatorname{lin}}$ & 384.24 & 1224.65 & 432.19 & 1043.43 \\
\hline (kN) & 383.34 & 1042.45 & 430.32 & 851.81 \\
\hline
\end{tabular}

表 41 次, 2 次固有モード形状

\begin{tabular}{|c|c|c|c|c|c|}
\hline & & \multicolumn{4}{|c|}{ initial shell } \\
\hline & & A2-model & A4-model & B2-model & B4-model \\
\hline \multirow{2}{*}{ 1次 } & $x y$ 平面 & 逆対称 & 逆対称 & 逆対称 & 対称 \\
\hline & $y z$ 平面 & 逆対称 & 逆対称 & 逆対称 & 对称 \\
\hline \multirow{2}{*}{ 2次 } & $x y$ 平面 & 逆対称 & 逆対称 & 逆対称 & 逆対称 \\
\hline & $y z$ 平面 & 逆対称 & 逆对称 & 逆対称 & 対称 \\
\hline
\end{tabular}

\begin{tabular}{|c|c|c|c|c|c|}
\hline & \multicolumn{4}{|c|}{ optimized shell } \\
\hline & & A2-model. & A4-model & B2-model & B4-model \\
\hline \multirow{2}{*}{ 1次 } & $x y$ 平面 & 逆対称 & 対称 & 逆対称 & 对称 \\
\hline & $y z$ 平面 & 逆对称 & 这対称 & 逆対称 & 巡対称 \\
\hline \multirow{2}{*}{ 2次 } & $x y$ 平面 & 対称 & 対称 & 逆对称 & 対称 \\
\hline & $y z$ 平面 & 逆対称 & 対称 & 対称 & 対称 \\
\hline
\end{tabular}

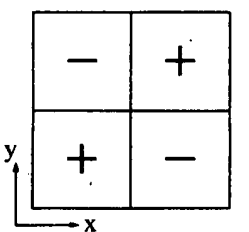

$※ 1$ 逆対称, 逆対称

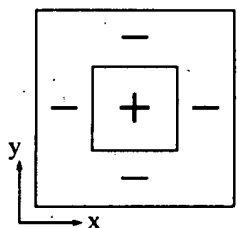

$※ 2$ 対称, 対称

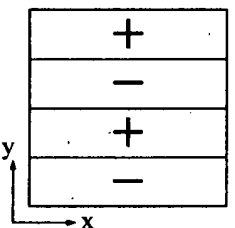

※ 3 逆対称, 対称
も，有効な解であることを明らかにしてきた。本節では，前節の解 析をもとに，形状初期不整を与えた場合の最適解の有効性について 検討する。

図 9 に最適形状 A2-modelに対する弾性非線形解析の荷重一変 位関係および各変形状態における 1 次， 2 次線形座屈荷重の推移を 示す。非線形座屈点に至るまでに固有值が入れ替わっており, 線形 固有值解析における 1 次固有モード形状と, 非線形座屈点における 1 次固有モード形状が異なっている。このことより，従来，1次固 有モ一ドと相似な形状を持つ形状初期不整が，座屈耐力に対し最も 影響を与えるとされているが，2次固有モ一ドの形状も影響が大き い場合もあると考えられる。したがって, 形状初期不整は完全形シェ ルの線形固有值解析から得られる 1 次抒よび 2 次固有モ一ドと相似

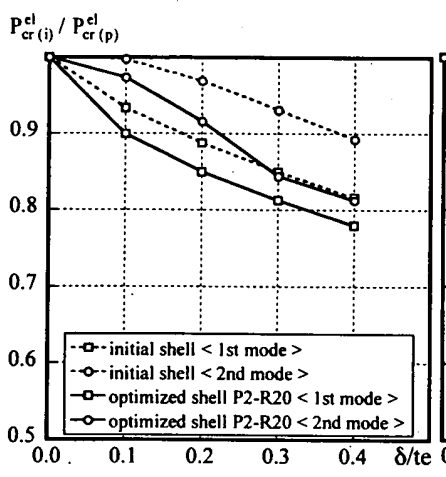

(1) A2-model

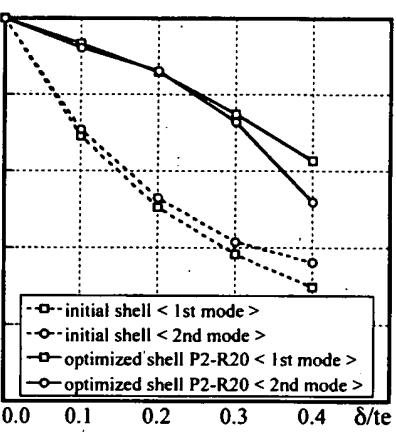

(2) A4-model
図10 最大不整振幅量と低減率の関係

なものを仮定し，完全形シェルの各節点に掠ける固有べクトルの八 ルムの最大俌が，等価シェル厚 te の $s(0.1,0.2,0.3,0.4)$ 倍になる ように不整振幅量 $\delta$ を基準化し与えることとする。表 4 に各モデル の 1 次, 2 次固有モード形状を示す。なお, 等価シェル厚 te は, 4 方向格子の場合も弦材のみを考慮し，直交 2 方向格子の有効剛性を 用いて求めることとする。本論では $t e=2 \sqrt{3} i$ とした。ここで， $i$ は 弦材における部材の断面 2 次半径である。

A-model $の$ 最大不整振幅量 $\delta$ と完全形シェルの非線形座屈荷重 $P_{c r(p)}^{e l}$ に対する初期不整を与えたシェルの非線形座屈荷重 $P_{c r(i)}^{e l}$ の 低減率 $P_{c r(i)}^{e l} / P_{c r(p)}^{e l}$ の関係を図10に示す。図中の点線は初期形状, 実 線は最適形状の解析結果であり, 口が 1 次固有モードを用いた場合, ○が 2 次固有モードを用いた場合を示す。(1) A2-model では, 初期 形状に比べ最適形状の不整敏感度は大きくなっているものの，その 差は小さく $5 \%$ 弱である。一方, (2) A4-model では, 最適形状の方 が不整敏感度が小さいという結果が得られた。ここには示していな いが, B2-model, B4-model は A2-model と同様の傾向を持つ結果 となっている。以上のことより, 初期形状と最適形状の初期不整敏 感度に差はなく，最適化を行ったことを理由とする敏感度の増大は 見られないと考えられる。

\section{8. 結論}

本論では, ベジエ曲面によって記述された単層ラチス自由曲面 シェルを対象として, 部材長さに関する制約条件の下, 線形座屈荷 重係数を最大化し, その上で部材長さを揃える工夫を試みることで, 力学的な観点と, 施工性の観点を融合した形状最適化について諭じ 
た。さらに最適解の力学特性を把握し, 幾何学的非線形性を考慮し た弾性非線形解析および形状初期不整に対する敏感性を検討を行う ことで, 解の有効性を検証した。構造物の力学的能力を十分に発揮 できる形態を創生し，また施工性やデザイン性を考慮することは， 今後需要が高まるであろう単層ラチス任意曲面シェルの可能性を広 げる試みであり，設計段階初期のデザインにおける一つの指標を提 案できると筆者らは考える。得られた結論を以下に示す。

（1）べジエ曲面を用いることで，スムーズな最適形状を得ることが でき，部材長さに関する制約条件を与えることにより，非現実的 な形状が得られ難くなる。

（2）線形座屈荷重を最大化することにより，2 次曲げ応力を抑えた， 軸力抵抗型の構造を持つラチスシェル形状となる。さらに, 格子 形状が直交でなくなる場合，テンションリングを持った構造とな る。

（3）最適化を数段階に分け, 部材をグルーピングしながら, 部材長 さの最大值と最小值の差を最小化することにより，線形座屈荷重 を考慮しながら，部材種類の少ない形状を得ることができる。

（4）弾性非線形解析を行った結果, 最適形状の非線形座屈荷重は初 期形状と比べて增加しており，最適形状は幾何学的非線形を考慮 した際も有効な形状であると言える。

（5）最適形状は軸力抵抗型の構造となるため, 形状初期不整に对す る敏感度が大きくなる可能性が示唆されるものの, 最適形状と初 期形状では敏感度に差はなく，最適化を行ったことによる目立っ た敏感度の增大は見られない。

\section{謝辞}

本研究の一部は，平成14年度科学研究費補助金基盤研究(C)(2)（課

題番号：14550560）によるものである。ここに謝意を表します。

\section{参考文献 .}

1）立石理恵, 小河利行, 大崎 純, 熊谷知彦：線形座屈荷重を目的関数とし た単層ラチスシェルの形状最適化，日本建築学会大会学術講演梗概集 (北 陸), B-1, pp.763-764, 2002.8

2) T. Ogawa, M. Ohsaki, R. Tateishi and T. Kumagai : Shape Optimiza tion of Single-layer Latticed Shells for Maximum Linear Buckling Loads, The Fifth International Conference of Space Structure, Vol. 2, pp.1345-1354, 2002

3) I.D. Faux and M.J. Pratt: Computational Geometry for Design and Manufacture, Ellis Horwood, 1979

4) G. Farin: Curves and Surfaces for Computer Aided Geometric Design, Academic Press, 1988

5) D.F. Rogers and J.A. Adams : Mathematical Elements for Computer Graphics, McGraw-Hill, 1990

6) E. Barnhill (Ed.) : Geometry Processing for Design and Manufacturing, SIAM, 1992

7) E. Ramm, K.-U. Bletzinger and R. Reitinger: Shape Optimization of Shell Structures, Bulletin of the International Association for Shell and Spatial Structures, Vol. 34 n.2(n.112), pp.103-121, 1993

8) M. Ohsaki and M. Hayashi : Fairness Metrics for Shape Optimization of Ribbed Shells, Journal of International Association for Shell and Spatial Structures, Vol. 41 No. 1, pp.31-39, 2000

9) M. Ohsaki, T. Nakamura and M. Kohiyama: Shape Optimization of Double-Layer Space Truss Described by a Parametric Surface, International Journal of Space Structures, Vol. 12 No. 2, pp.109-119, 1997

10）小河利行, 桑田真理子：鉛直荷重を受ける剛接合単層ラチスドームの弾塑 性座屈性状，日本建築学会構造系論文集，第506号，pp.131-138，1998.4 11）小河利行, 加藤史郎, 萩原真祐子, 立石理恵：等分布荷重を受ける単層 HP ラチスシェルの座屰挙動と耐力評価, 日本建築学会構造系論文集, 第553 号, pp.65-72, 2002.3

12) T. Ogawa, M. Ohsaki, Y. Nishikawa and R. Tateishi : Mechanical Properties of Two-way Grid Shells Optimized Considering Roundness and Elastic Stiffness, The Second China-Japan-Korea Joint Symposium on Optimization of Structural and Mechanical Systems, pp. 201-206, 2002

13）大森博司, 山本憲司：応力分布を目的関数とする空間構造物の形状最適化 に関する研究 その1シェル構造への適用, 日本建築学会構造系論文集, 第496号, pp.67-73, 1997.6

14）大森博司, 山本慧司：応力分布を目的関数とする架間構造物の形状最適化 に関する研究 その 2 スペースフレームへの適用, 日本建築学会構造系論 文集，第503号，pp.77-83，1998.1

15) W. Prager, J.E. Taylor: Problems of Optimal Structural Design, Journal of Applied Mechanics, Vol. 35, pp.102-106, 1968

16) N. Olhoff and S.H. Rasmussen: On Single and Bimodal Optimum Buckling Loads of Clamped Columns, Int. J. Solids Struct., pp.605-614, 1977

17) N.S. Khot, V.B. Venkayya and L. Berke : Optimum Structural Design with Stability Constraints, Int. J. Num. Meth. Engng., Vol.10, pp. 1097-1114, 1976

18）陳沛山, 川口 衙：スペースフレームの最大座屈荷重形態, 日本建築学 会構造系論文集，第489号，pp.41-46，1996.11

19) M. Ohsaki and T. Nakamura: Optimum Design with Imperfection Sensitivity Coefficients for Limit Point Load, Structural Optimization, Vol. 8, pp.131-137, 1994

20) M. Ohsaki, K. Uetani and M. Takeuchi: Optimization of Imperfection-sensitive Symmetric Systems for Specified Maximum Load Factor, Computer Methods in Applied Mechanics and Engineering, Vol. 166, pp.349-362, 1998

21) M. Ohsaki: Optimization of Geometrically Nonlinear Symmetric Systems with Coincident Critical Points, International Journal for Numerical Methods in Engineering, Vol. 48, pp.1345-1357, 2000

22) Recommendations for Reinforced Concrete Shells and Folded Plates, International Association for Shell and Spatial Structures, working group nr 5, 1979

23）山田聖志, 竹内明子, 多田敬幸, 堤 和敏：沉用構造解析コードによる RS 解析法と単層ラチスドームの座屈問題への適用, 日本建築学会構造系論文 集, 第526号, pp.85-92, 1999.12

24）小河利行, 桑田真理子：形状初期不整の分布形状が剛接合単層ラチスドー 么の弾塑性座屈荷重に与之る影響, 日本建築学会構造系論文集, 第531号, pp.109-115, 2000.5

25) M.P. Kamat, N.S. Khot and V.B. Venkayya: Optimization of Shallow Trusses Against Limit Point Instability, AIAA Journal, Vol. 22 No. 3, pp.403-408, 1984

26) R. Levy and H.-S. Perng: Optimization for Nonlinear Stability, Computers \& Structures, Vol. 30 No. 3, pp.529-535, 1988

27）山本憲司, 皆川洋一, 大森博司：座屈荷重を目的関数とする空間構造の形 状最適化に関する研究：日本建築学会構造系論文集, 第564号, pp.95-102, 2003.2

28) M. Ohsaki : Structural Optimization for Specified Nonlinear Buckling Load Factor, Japan Journal of Induscrial and Applied Math. ematics, Vol. 19, pp.163-179, 2002

29）石川浩一郎，池畑勝仙，西村圭介：Geometric Potential 最小化によるラ チスドームのグリッド分割法, 日本建築学会技術報告集, 第 9 号, pp. 83-88, 1999.12

30）大澤義明，木島安史：ドーム表面の不規則な三角形分割に関する研究，日 本建築学会計画系論文報告集，第425号，pp.87-92，1991.7

31) T. Tarnai : Optimization of Spherical Networks for Geodesic Domes, Proceeding Third International Conference of Space Structure, pp. 100-104, Elsevier Applied Science Publishers, 1984

（2003年1月10日原稿受理，2003年 5 月 26 日採用決定） 